\title{
The Serial/Monograph Ratio in Research Libraries: Budgeting in Light of Citation Studies
}

\section{Robin B. Devin and Martha Kellogg}

Librarians are concerned with the ever-increasing portion of the budget being devoted to serials. No formula or objective guideline presently exists to determine the correct allocation ratio for serials vs. monographs. Over the past 40 years, over 50 studies have analyzed the use of the research literature in various subject areas. These studies use citation analysis to determine the actual percentage of serials vs. monographs used by researchers in each field. The present study uses these figures to provide a guideline for serial vs. monograph budgeting.

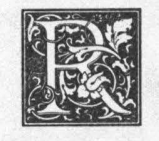

esearch library collections have faced a complex budget squeeze for more than ten years. Escalating prices and burgeoning numbers of journals combined with limited budgets have placed tremendous pressure on research libraries to maintain a "balanced" collection of serials and monographs to meet the educational and research requirements of students and faculty. The ratio of serials to monographs has been a concern in academic libraries since the 1970 s as serial subscription costs have outstripped other materials costs. Librarians view with alarm the trend toward devoting a larger proportion of the materials budget to serials. University libraries have undertaken major serials deselection projects in reaction to the perceived imbalance in the serial/monograph budget ratio. This paper will review causes of the serial/monograph budget squeeze, reactions in the lit- erature, and responses of libraries to the problem. It will present a method for determining reasonable serial/monograph budget ratios for research libraries.

A serial is now identified by most authorities in terms of the AACR2 definition: "A publication in any medium issued in successive parts bearing numerical or chronological designations and intended to be continued indefinitely." ${ }^{\text {"1 }}$ Although serials take on many different forms (periodicals, journals, newspapers, magazines, annuals, proceedings, etc.), libraries acquire the majority of them by subscription (payment in advance of publication), a characteristic which often constitutes a fixed cost in the library's budget.

\section{COPING WITH THE SERIALS EXPLOSION}

Library materials budgets have been unable to keep up with the escalating numbers and costs of serials. White reported

Robin B. Devin is Head, Acquisitions Department and Martha Kellogg is Assistant Acquisitions Librarian at the University of Rhode Island, Kingston, Rhode Island 02881-0803. 
on studies of the Indiana University Research Center for Library and Information Science on the interaction of libraries and scholarly publishers for ten years starting in 1969. Strategies devised by libraries to cope with the budget crisis included the following:

1. Libraries tended to freeze periodical budgets at their current level and cut down drastically on new subscriptions.

2. Libraries cancelled duplicate subscriptions.

3. Libraries cancelled foreign titles (especially foreign language titles).

4. Libraries did not make cancellation decisions based on availability from other sources.

5. Libraries did not cancel because of price. $^{2}$

When these strategies were insufficient to maintain serials collections within the budget, libraries coped, White concludes, by transferring funds from the monograph budget to the serial budget. $\mathrm{He}$ notes: in 1969, academic libraries spent $\$ 2.00$ on books for every $\$ 1.00$ on serials. In 1973 , they spent $\$ 1.16$ on books for every $\$ 1.00$ on serials. In 1976 , they spent $\$ 1.23$ on serials for every $\$ 1.00$ on books. ${ }^{3}$ The serial/monograph budget ratio had shifted in favor of serials for the first time.

Other authors have pointed with growing anxiety to the same phenomenon. Taylor reiterates: "Since it is difficult to forecast the exact cost of serial renewals, some [libraries] have merely treated serial renewals as a fixed cost and used one fund for serials and book purchases. . . . After the serials have been paid for, what is left is available for books. The book fund has had to bail out the serial fund when the serial fund is inadequate for the purpose..$^{\prime 4}$

Statistics show that, indeed, a greater percentage of academic library budgets is now devoted to serials than to monographs. But available data from the Association of College and Research Libraries (ACRL) and the Association of Research Libraries (ARL) indicate that this change is not as dramatic as one might assume, considering the tremendous growth in the numbers and costs of serial publications. "Serials Expenditures as Percent of Materials Expenditures," published in the ARL and ACRL table, Analysis of Selected Variables of University Libraries, reveals that the median has actually changed very little in the last ten years. As can be seen in table 1 , the ratio of serial to monographic expenditures has shifted slightly in favor of serials, but the median in academic libraries has fluctuated between 45 to $57 \%$. Although some academic libraries spend two-thirds or more of their materials budget on serials, others spend one-third or less, and the median has stayed below $60 \%$.

Additional funds to cope with serial costs have not come from other areas of the university budget. "Materials Expenditures as Percent of Total Operating Expenditures," from the same ACRL and ARL tables, shows that the materials budget as a percentage of library expenditures has remained virtually constant over the same period. Table 2 presents available statistics on the relationship between the materials budget and the total operating budget of academic libraries reporting to ACRL and ARL.

With academic library materials budgets remaining relatively constant (some growing at the rate of inflation, others remaining constant, some even decreasing), the

TABLE 1

SERIALS EXPENDITURES AS PERCENT OF MATERIALS EXPENDITURES

\begin{tabular}{lcccc}
\hline \hline Date & & High & Median & Low \\
\hline ACRL * & $1978-79$ & 82 & 49 & 15 \\
& $1983-84$ & 92 & 45 & 25 \\
ARL $^{+}$ & $1985-86$ & 97 & 51 & 27 \\
& $1980-81$ & 83 & 57 & 36 \\
& $1982-83$ & 71 & 54 & 30 \\
& $1983-84$ & 77 & 55 & 33 \\
& $1984-85$ & 77 & 53 & 34 \\
& $1986-87$ & 75 & 56 & 32 \\
\hline
\end{tabular}

* ACRL University Library Statistics 1978-1979 (Chicago: Association of College and Research Libraries, 1980); ACRL University Library Statistics, 1983-84 (Chicago: Association of College and Research Libraries, 1985); ACRL University Library Statistics, 1985-86 \& 1986 "100 Libraries" Statistical Survey (Chicago: Association of College and Research Libraries, 1987).

+ ARL Statistics, 1980-81 (Washington, D.C.: Association of Research Libraries, 1981); ARL Statistics, 1982-83 (Washington, D.C.: Association of Research Libraries, 1984); ARL Statistics, 1983-84 (Washington, D.C.: Association of Research Libraries, 1985); ARL Statistics, 1984-85 (Washington, D.C.: Association of Research Libraries, 1986); ARL Statistics, 1986-87 (Washington, D.C.: Association of Research Libraries, 1988). 
TABLE 2

MATERIALS EXPENDITURES AS PERCENT OF TOTAL OPERATING EXPENDITURES

\begin{tabular}{lcccc}
\hline \hline Date & & High & Median & Low \\
\hline ACRL $^{*}$ & $1978-79$ & 55 & 36 & 19 \\
& $1983-84$ & 54 & 37 & 19 \\
& $1985-86$ & 47 & 35 & 17 \\
ARL $^{+}$ & $1980-81$ & 44 & 32 & 20 \\
& $1982-83$ & 47 & 32 & 20 \\
& $1983-84$ & 50 & 32 & 17 \\
& $1984-85$ & 48 & 32 & 22 \\
& $1986-87$ & 49 & 34 & 20 \\
\hline
\end{tabular}

* ACRL University Library Statistics 1978-1979 (Chicago: Association of College and Research Libraries, 1980); ACRL University Library Statistics, 1983-84 (Chicago: Association of College and Research Libraries, 1985); ACRL University Library Statistics, 1985-86 \& 1986 "100 Libraries" Statistical Survey (Chicago: Association of College and Research Libraries, 1987).

+ ARL Statistics, 1980-81 (Washington, D.C.: Association of Research Libraries, 1981); ARL Statistics, 1982-83 (Washington, D.C.: Association of Research Libraries, 1984); ARL Statistics, 1983-84 (Washington, D.C.: Association of Research Libraries, 1985); ARL Statistics, 1984-85 (Washington, D.C.: Association of Research Libraries, 1986); ARL Statistics, 1986-87 (Washington, D.C.: Association of Research Libraries, 1988).

serials budget has been caught in a squeeze. The number, cost, and importance of serial publications have grown dramatically during the latter half of the twentieth century, but library resources have not kept pace. Competition for scarce resources has affected the budget allocation between serials and monographs in academic libraries.

\section{ALLOCATION OF THE MATERIALS BUDGET}

Allocation of the materials budget among competing interests is at the heart of academic librarianship. It concerns acquisitions and collection development librarians, subject specialists, administrators, and the teaching faculty. The concept of allocating book budget funds by formula among the various university departments has long been advocated in the literature. ${ }^{5}$ Allocation formulas may be quite complex, assigning numerical weights to many variables considered important in distributing funds among subjects or departments. As summarized by Kohut and Walker, four major factors have generally been considered in allocation formulas: (1) subjective judgments based on collection evaluations and historical inequities; (2) size of academic departments (number of students, credit

\section{"Most allocation formulas deal with the book budget, leaving serials as a fixed cost not allocated by subject.'}

hours, faculty, etc.); (3) level of program (graduate/undergraduate) and library usage; and (4) size of the published literature. ${ }^{6}$ Each library assigns numerical values to these factors (and sometimes dozens of other variables ${ }^{7}$ ) based on its own programs and emphases to arrive at an allocation for the academic departments at that institution.

Most allocation formulas deal with the book budget, leaving serials as a fixed cost not allocated by subject. (Kohut provided a model which takes into account the differential rate of cost increase, especially among serials. ${ }^{8} \mathrm{He}$ assumed, however, that that allocation among departments and the serial/monograph ratio within departments had already been determined.) Department allocations based on most formulas provide an equitable balance for book acquisitions. When serial subscriptions are treated as a fixed cost, however, the explosive growth in number and price of serial publications has created serious problems with the allocation of the materials budget. It has led to the recent concern for the serial/monograph budget ratio in academic libraries.

\section{THE SERIAL/ MONOGRAPH RATIO}

The importance of determining a rational ratio between serials and monographs within a limited materials budget has assumed greater importance under the circumstances detailed above. A review of the literature, however, yields little guidance for determining what the balance should be. Stueart and Miller maintain:

The question as to what proportion of a library's acquisitions funds should be allocated for serial commitments has been asked ever more frequently as costs have risen and budgets have lagged. There can be no definitive answer, even for a given type and size of library. No single recommendation can be made as to the proportions of a book budget that should be 
spent on the two major types of publication [serials, monographs]. . . There is no general agreement on the desirable ratio, but collection development officers seem to feel uneasy when periodical expenditures rise far above $60 \%$.

According to Magrill and Hickey: "Without question, one of the knottiest problems in many large research libraries is the distribution of limited acquisitions money between monographs and serials." 10

Standards and guidelines for academic libraries developed by the American Library Association (ALA) recognize generally that budget allocation is necessary, but remain silent on the issue of a budget ratio between serials and monographs. ALA's Standards for University Libraries states only that "a university library's collections shall contain all of the varied forms of recorded information." ${ }^{\prime 11}$ ALA's $^{\prime}$ "Guidelines for the Allocation of Library Materials Budgets" suggests allocation by form, by subject, or a combination of both, but presents no ratio between the two major forms of publication. ${ }^{12}$

Since monographs consumed the lion's share of the materials budget (often referred to as the "book budget") until the mid-1970s, the idea of a reasonable se$\mathrm{rial} /$ monograph ratio is a comparatively recent concept. To a certain extent, the concept implies a fear that the monograph collection will be overwhelmed by a deluge of serials. As Kohut noted: "Implicit in the concern about serials costs is the assumption that too much of the book budget is devoted to serials. Most libraries could balance the acquisition of monographs with serials so as to maximize their potential to serve the university's information needs. ${ }^{13}$ Kohut also pointed out that a reasonable ratio between monographs and serials in a university library varies depending on the subject discipline: "Every discipline has its own optimal ratio between serials and monographs." ${ }^{\prime 14}$

White, while detailing libraries' ineffectual attempts to deal with the budget crunch, recognized that there is a relationship between the use of different types of literature and academic discipline.

Of course, this shift from the monographic to the serials budget impacts some disciplines more than others. The physical sciences, in general, are strongly dependent on the periodical literature. The humanities, on the other hand, are far more oriented to monographs. Where shifts have taken place across departmental disciplines, there has been a shift in emphasis. There is nothing necessarily wrong with this, as long as it is done consciously. ${ }^{15}$

Swindler develops the theme that librarians, as traditional "book people," have had little understanding of library resources beyond the monograph, and that, until the recent financial crisis, "serials were quite neglected in comparison to books. ${ }^{116}$ Budget allocations, he suggests, should take into account both types of literature according to their importance within subject disciplines.

Depending on the programs, serials can be vitally important-often more essential than books in many subject areas and for satisfying certain needs. The tendency of libraries to budget primarily by format not only does not make sense in terms of supporting programs with the most appropriate configuration of resources, but a budgetary model based on format impairs the institution's ability to meet needs equitably, given the traditional bias toward maximizing the number of books purchased and the relatively new trend of arbitrarily setting a limit to how much the library will spend on serials subscriptions. Rather, expenditures should be considered as part of a consolidated budget allocation for the support of a particular program. ${ }^{17}$

Although Swindler suggests that the ratio between serials and monographs will vary depending on the discipline, he does not specify how the consolidated budget allocation for particular programs can be determined.

\section{DETERMINING THE RATIO}

It is our contention that a reasonable budget ratio between serials and monographs for individual subject disciplines can be determined. A serial vs. monograph budget allocation can be made using statistics provided in studies on the characteristics of literature usage in each subject area. Over the past 60 years, numerous articles have been published that characterize the use of the research literature in various fields. These studies have been conducted by selecting journal articles or other research done in specific subject areas and analyzing the references 
TABLE 3

SERIALS USE BY SUBJECT

\begin{tabular}{|c|c|c|c|}
\hline LC Class & Subject & Citation & $\%$ Serials Use \\
\hline $\mathrm{A}$ & American Studies & Bolles $^{1}$ & 42.6 \\
\hline BL-BX & Theology & Whalen ${ }^{2}$ & 23.3 \\
\hline BL-BX & Theology & Heussman $^{3}$ & 24.8 \\
\hline D-F & History & Baughman ${ }_{5}^{4}$ & 23.3 \\
\hline DA & English History & Jones $^{5}$ & 27.1 \\
\hline $\mathrm{M}$ & Music & Vaughan $^{6}$ & 28.2 \\
\hline M & Music & Baker ${ }^{7}$ & 23.5 \\
\hline $\mathrm{N}$ & Fine Arts & Simonton ${ }^{8}$ & 28.6 \\
\hline $\mathrm{P}$ & Philology & Tucker $^{9}$ & 38.4 \\
\hline PA & Classics & Tucker $^{10}$ & 28.5 \\
\hline PN & Speech & Broadus $(1953)^{11}$ & 45.7 \\
\hline $\mathrm{P}$ & Literature & Stern $^{12}$ & 15.0 \\
\hline PR-PS & British and American Literature & Cullars $(1985)^{13}$ & 13.3 \\
\hline $\mathrm{P}$ & English Literature & Chambers ${ }^{14}$ & 28.1 \\
\hline $\mathrm{P}$ & English Literature & Heinzkill $^{15}$ & 19.9 \\
\hline$P$ & Foreign Literature & Cullars $(1988)^{16}$ & 10.9 \\
\hline & Social Sciences & Guttsman $^{17}$ & 36.0 \\
\hline & Social Sciences & Earle $^{18}$ & 29.0 \\
\hline & Social Sciences & Garfield(1976) $)^{19}$ & 38.0 \\
\hline BF & Psychology & Xhignesse $^{20}$ & 35.0 \\
\hline GN & Anthropology & Baughman $(1977)^{21}$ & 42.9 \\
\hline $\mathrm{HB}$ & Economics & Fletcher ${ }^{22}$ & 47.3 \\
\hline $\mathrm{HB}$ & Economics & Baughman $(1977)^{23}$ & 59.0 \\
\hline $\mathrm{HD}$ & Agricultural Economics & Littleton $^{24}$ & 31.4 \\
\hline HD-HJ & Business Administration & Sarle $^{25}$ & 42.3 \\
\hline HD-HJ & Business & Popovich ${ }^{26}$ & 58.6 \\
\hline $\mathrm{HM}-\mathrm{HV}$ & Sociology & Broadus $(1952)^{27}$ & 46.3 \\
\hline HM-HV & Sociology & Broadus $(1967)^{28}$ & 38.5 \\
\hline HM-HV & Sociology & $\operatorname{Lin}^{29}$ & 38.8 \\
\hline HM-HV & Sociology & Baughman $(1974)^{30}$ & 38.5 \\
\hline HM-HV & Sociology & Baughman $(1977)^{31}$ & 44.4 \\
\hline & Political Science & Baum $^{32}$ & 31.5 \\
\hline & Political Science & Baughman $(1977)^{33}$ & 34.6 \\
\hline JF & Public Administration & Intrama $^{34}$ & 26.1 \\
\hline $\mathrm{L}$ & Education & Broadus $(1953)^{35}$ & 42.6 \\
\hline $\mathrm{L}$ & Education & Chambers ${ }^{36}$ & 40.5 \\
\hline $\mathrm{L}$ & Education & Mochida $^{37}$ & 41.7 \\
\hline $\mathrm{Z}$ & Library Science & Barnard ${ }^{38}$ & 52.3 \\
\hline $\mathrm{Z}$ & Library Science & Penner $^{39}$ & 50.7 \\
\hline $\bar{Z}$ & Library Science & Brace $^{40}$ & 33.0 \\
\hline $\mathrm{Z}$ & Library Science & LaBorie $^{41}$ & 28.2 \\
\hline & Science & Garfield $(1976)^{42}$ & 80.0 \\
\hline & Science & Earle $^{43}$ & 82.0 \\
\hline QA & Mathematics & Brown ${ }^{44}$ & 76.8 \\
\hline QB & Astronomy & Lang $^{45}$ & 85.4 \\
\hline $\mathrm{QC}$ & Optics & $\operatorname{Lin}^{46}$ & 76.5 \\
\hline Q⿳亠二口犬 & Physics & Fussler ${ }^{47}$ & 89.7 \\
\hline QC & Physics & Brown ${ }^{48}$ & 88.8 \\
\hline QD & Chemistry & Fussler ${ }^{49}$ & 92.9 \\
\hline QDD & Chemistry & Barker $_{51}^{50}$ & 86.1 \\
\hline QD & Chemistry & Brown ${ }^{51}$ & 93.6 \\
\hline $\mathrm{QE}$ & Geology & Gross $^{52}$ & 85.4 \\
\hline QE & Geology & Laosunthara $^{53}$ & 83.0 \\
\hline $\mathrm{QE}$ & Geology & Craig $^{54}$ & 77.4 \\
\hline QE & Geology & Brown ${ }^{55}$ & 87.2 \\
\hline QK & Botany & Hintz ${ }^{56}$ & 86.3 \\
\hline Q̄K & Botany & Brown $n_{58}^{57}$ & 82.7 \\
\hline $\mathrm{QL}$ & Zoology & Brown $n^{58}$ & 80.8 \\
\hline Q̄L & Entomology & Brown $n^{59}$ & 81.2 \\
\hline QP & Physiology & Brown $^{60}$ & 90.8 \\
\hline QR & Microbiology & Kanasy $^{61}$ & 93.1 \\
\hline $\mathrm{R}$ & Medicine & Sherwood $^{62}$ & 85.2 \\
\hline $\mathrm{T}$ & Technology & Earle $^{63}$ & 70.0 \\
\hline $\mathrm{T}$ & Engineering & Waldhart $^{64}$ & 72.4 \\
\hline TK & Electrical Engineering & Coile $^{65}$ & 61.9 \\
\hline TP & Chemical Engineering & Patterson $^{66}$ & 75.8 \\
\hline
\end{tabular}




\section{TABLE 3 Cont.}

\section{REFERENCES}

1. Charles A. Bolles, "Characteristics of the Literature of American Studies as Indicated by Bibliographic Citations" (Ph.D. diss., Univ. of Minnesota, 1975).

2. Sr. Mary L. Whalen, "The Literature Used in Catholic and Protestant Doctoral Research in Theology" (Ph.D. diss., Columbia Univ., 1965).

3. John W. Heussman, "The Literature Cited in Theological Journals and Its Relation to Seminary Library Circulation" (Ph.D. diss. Univ. of Illinois, 1970).

4. James C. Baughman, "Toward a Structural Approach to Collection Development," College \& Research Libraries 38:241-48 (May 1977)

5. Clyve Jones, Michael Chapman and Pamela C. Woods, "The Characteristics of the Literature Used by Historians," Journal of Librarianship 4:137-56 (July 1972).

6. David L. Vaughan, "Characteristics of the Literature Cited by Authors of Articles in The Musical Quarterly, 1955-58 and The American Musicological Society Journal, 1953-56" (Master's thesis, Univ. of North Carolina, 1959).

7. David Baker, "Characteristics of the Literature Used by English Musicologists," Journal of Librarianship 10:182-200 (July 1978).

8. Wesley C. Simonton, "Characteristics of the Research Literature of the Fine Arts During the Period 1948-1957" (Ph.D. diss., Univ. of Illinois, 1960).

9. B. R. Tucker, "Characteristics of the Literature Cited by Authors of the Transactions of the American Philological Association, 1956 and 1957"' (Master's thesis, Univ. of North Carolina, 1959).

10. Ibid.

11. Robert N. Broadus, The Research Literature of the Field of Speech. A.C.R.L. Monograph no.7 (Chicago: Association of College and Reference Libraries, 1953).

12. Madeleine Stern, "Characteristics of the Literature of Literary Scholarship," College \& Research Libraries 44:199-209 (July 1983).

13. John Cullars, "Characteristics of the Monographic Literature of British and American Literary Studies," College \& Research Libraries 46:511-22 (Nov. 1985).

14. George R. Chambers and Jamès S. Healey, "Journal Citations in Master's Theses: One Measurement of a Journal Collection," Journal of American Society for Information Science 24:397-401 (Sept.-Oct. 1973).

15. Richard Heinzkill, "Characteristics of References in Selected Scholarly English Literary Journals," Library Quarterly 50:352-65 (July 1980).

16. John Cullars, "Characteristics of the Monographic Scholarship of Foreign Literary Studies by Native Speakers of English," College \& Research Libraries 49:157-70 (March 1988).

17. W. L. Guttsman, "The Literature of the Social Sciences and Provision for Research in Them," Journal of Documentation 22:186-94 (Sept. 1966)

18. Penelope Earle and Brian Vickery, "Social Science Literature Use in the UK as Indicated by Citations," Journal of Documentation 25:123-41 (June 1969).

19. Eugene Garfield, "Anonymity in Refereeing? Maybe-But Anonymity in Authorship? No!," Current Contents: Engineering, Technology, \& Applied Science 7 no.11:5-7 (March 15, 1976).

20. Louis V. Xhignesse and Charles E. Osgood, "Bibliographical Citation Characteristics of the Psychological Journal Network in 1950 and in 1960," American Psychologist 22:778-91 (1967).

21. Baughman, "Toward a Structural Approach to Collection Development."

22. John Fletcher, "A View of the Literature of Economics," Journal of Documentation 28:283-95 (Dec. 1972).

23. Baughman, "Toward a Structural Approach to Collection Development."

24. Isaac T. Littleton, "The Bibliographic Organization and Use of the Literature of Agricultural Economics," (Ph.D. diss., Univ. of Illinois, 1968).

25. Rodney G. Sarle, "Characteristics of the Literature Used by Authors of Journal Articles in Business Administration," (Master's thesis, Univ. of North Carolina, 1958).

26. Charles J. Popovich, "The Characteristics of a Collection for Research in Business/Management," College \& Research Libraries 39:110-17 (March 1978).

27. Robert N. Broadus, "An Analysis of Literature Cited in the American Sociological Review, " American Sociological Review 17:355-57 (June 1952).

28. Robert N. Broadus, "A Citation Study for Sociology," American Sociologist 2:19-20 (Feb. 1967).

29. Nan Lin and Carnot E. Nelson, "Bibliographic Reference Patterns in Core Sociological Journals, 1965-1966," American Sociologist 4:47-50 (Feb. 1969).

30. James C. Baughman, "A Structural Analysis of the Literature of Sociology," Library Quarterly 44:293-308 (Oct. 1974).

31. Baughman, "Toward a Structural Approach to Collection Development."

32. William C. Baum, "American Political Science Before the Mirror: What Our Journals Reveal About the Profession," Journal of Politics 38:895-917 (1976).

33. Baughman, "Toward a Structural Approach to Collection Development."

34. Navanitaya Intrama, "Some Characteristics of the Literature of Public Administration," (Ph.D. diss., Indiana Univ., 1968).

35. Robert N. Broadus, "The Literature of Educational Research," School and Society 77:8-10 (Jan. 1953).

36. Chambers and Healey, "Journal Citations in Master's Theses."

37. Paula Mochida, "Citation Survey of Education Literature," Hawaii Library Association Journal 33:29-42 (1976).

38. Walter M. Barnard, "Characteristics of the Literature Used by American Authors of Journal Articles in Library Science," (Master's thesis, Univ, of North Carolina, 1957).

39. Rudolf J. Penner, "Measuring a Library's Capability ... ., Journal of Education for Librarianship 13:17-30 (Summer 1972).

40. William Brace, "Frequently Cited Authors and Periodicals in Library and Information Science Dissertations; 1961-1970," Journal of Library and Information Science 2:16-34 (April 1976).

41. Tim LaBorie and Michael Halperin, "Citation Patterns in Library Science Dissertations," Journal of Education for Librarianship 16:271-83 (Spring 1976).

42. Garfield, "Anonymity in Refereeing."

43. Earle and Vickery, "Social Science Literature Use in the UK."

44. Charles H. Brown, Scientific Serials: Characteristics and Lists of Most Cited Publications in Mathematics, Physics, Chemistry, Geology, Physiology, Botany, Zoology, and Entomology. ACRL Monograph no.16 (Chicago: Association of College and Reference Libraries, 1956).

45. Norma L. F. Lang, "Characteristics of the Serial Literature of Astronomy," (Master's thesis, Southern Connecticut State College, 1966). 


\section{TABLE 3 Cont.}

46. Lin and Nelson, "Bibliographic Reference Patterns."

47. Herman H. Fussler, "Characteristics of the Research Literature Used by Chemists and Physicists in the United States, Part II," Library Quarterly 19:119-43 (April 1949).

48. Brown, Scientific Serials.

49. Fussler, "Characteristics of the Research Literature."

50. Dale Barker, "Characteristics of the Scientific Literature Cited by Chemists of the Soviet Union," (Ph.D. diss., Univ. of Illinois, 1966).

51. Brown, Scientific Serials.

52. P. L. K. Gross and A. O. Woodford, "Serial Literature Used by American Geologists," Science 73:660-64 (June 1931).

53. Maria Laosunthara, "Some Bibliographical Characteristics of Serial Literature in the Field of Geology," (Ph.D. diss., Indiana Univ., 1956).

54. J. E. G. Craig, "Characteristics of Use of Geology Literature," College \& Research Libraries 30:230-36 (May 1969).

55. Brown, Scientific Serials.

56. Carl W. E. Hintz, "Internationalism and Scholarship: A Comparative Study of the Research Literature Used by American, British, French, and German Botanists," (Ph.D. diss., Univ. of Chicăgo, 1952.)

57. Brown, Scientific Serials.

58. Ibid.

59. Ibid.

60. Ibid.

61. James E. Kanasy, "Citation Characteristics and Bibliographic Control of the Literature of Microbiology," (Ph.D. diss., Univ. of Pittsburgh, 1971).

62. K. K. Sherwood, "Relative Value of Medical Magazines," Northwest Medicine 31:273-76 (June 1932).

63. Earle and Vickery, "Social Science Literature Use in the UK."

64. Thomas J. Waldhart, "The Relationship Between the Citation of Scientific Literature and the Institutional Affiliation of Engineers," (Ph.D. diss., Indiana Univ. 1973).

65. Russell C. Coile, "Information Sources for Electrical and Electronic Engineers," I.E.E.E. Transactions on Engineering Writing and Speech 12:71-78 (October 1969).

66. Austin M. Patterson, "Literature References in Industrial and Engineering Chemistry for 1939," Journal of Chemical Education 22:514-15 (Oct. 1945).

cited. The references are then categorized by form and the percentage of use of the various categories is given.

To date more than 50 such articles have appeared. They cover almost the entire spectrum of subjects from the fine arts to engineering. These studies provide statistics on the use researchers make of serial versus monograph literature in their fields. Not every study categorizes the references cited in quite the same way, but it is possible in most cases to extract the total percentage of serial usage.

One of the most striking results of these various studies is the consistency of the data they provide. In certain subject areas this type of citation analysis has been conducted by numerous researchers over a substantial time span with similar results. In the field of sociology, for example, five studies of journal citations conducted over a 23-year-period gave serial use percentages ranging from $28-46 \%$ (see table 3 ). In fact, three of these studies by different authors found the same figure of $38 \%$ serial use.

Even when the materials analyzed are different, the percentage of serial use is very similar within a discipline. Three studies of sources in the field of education cited in table 3 illustrate this point. In 1953 Broadus did a study of the form of literature cited in the Encyclopedia of Educational Research and found that $42.6 \%$ of the citations were to serials. Chambers, in 1973, studied citations in master's theses and found a serial citation percentage of $40.5 \%$. Finally, in 1976 Mochida studied citations in journal articles and found that serial citations accounted for $41.7 \%$ of the total.

Table 3, "Serial Use by Subject," provides a summary of the data on serial versus monograph use given in these studies.

Most librarians have long been aware that researchers in the sciences rely much more on serials than do researchers in the humanities. Yet this information has not been translated into the budget allocation process. We have found that the data provided in these studies can be used to determine how much should be allocated for serials versus monographs in each subject area. The percentage of serial usage can be directly applied to the budgeting process.

Many libraries use some variation of an allocation formula to divide their monograph budget into subject categories. These monograph allocation figures can then be used as a basis for determining the 


\section{"Using this formula, one could find, for example, that a library allocating $\$ 10,000$ for the purchase of mono- graphs in the fine arts should be allo- cating approximately $\$ 4,000$ for seri- als in that subject."}

guidelines for serials expenditures in those areas. Using the serial use percentage given in table 3 , the serial allocation is determined by multiplying the monograph allocation figure $(\mathrm{M})$ by the serial percentage $(\%)$ given in table 3 for that subject and dividing by ( 100 - that same percentage) as in the following formula:

$$
S=\frac{(M)(\%)}{(100-\%)}
$$

Using this formula, one could find, for example, that a library allocating $(\$ 10,000)$ for the purchase of monographs in the fine arts should be allocating approximately $\$ 4,000$ for serials in that subject.

$$
\frac{(10,000)(28.6 \%)}{(100-28.6 \%)}=\$ 4,005
$$

A library may also use its serial allocation breakdown to determine a guideline for monograph expenditures. The formula would then be

$$
M=\frac{S}{\%}-S .
$$

The use of either of these formulas assumes that funds for each subject should be allocated between serials and monographs in the same proportion as each form of literature is used by the researcher. Thus, if fine arts research has a serial citation rate of $28.6 \%$, then $28.6 \%$ of the library materials budget for the fine arts should be allocated to serials.

At first glance it appears that such a simplistic formula fails to take into account a number of factors generally believed to be important when establishing allocations. However, it must be remembered that the formula is actually only establishing a ratio between serial and monograph bud- gets within each subject area. Most of the factors such as collection intensity, number of students and faculty in the area, circulation statistics, and average cost per volume should have already been taken into consideration when the original monograph (or serial) allocation was made. The application of the formula just translates that dollar figure into a corresponding serial (or monograph) dollar figure using the citation ratio.

Once the percentages from table 3 have been used to establish the guidelines for serial versus monograph budgeting of each subject area, the individual figures can be totaled to determine an overall guideline for serial versus monograph spending. This method therefore links the library's budget allocation to the actual use of library material by researchers in each subject area.

\section{CONCLUSION}

The information explosion of the late twentieth century has placed a severe strain on the materials budgets of research libraries. University libraries that must support teaching and research in traditional disciplines as well as in emerging programs have been hard pressed to meet the needs of students and faculty. Massive increases in the number and price of serial publications have exacerbated the problem, and serial purchasing has come under closer scrutiny than ever before.

Statistics reveal that in the mid-1970s research libraries, for the first time, spent a larger share of their materials budgets on serials than on monographs. This unprecedented development led to the concept of a ratio between serials and monographs for budgeting purposes. But a search of the literature discloses no objective guideline for determining the optimum se$\mathrm{rial} / \mathrm{monograph}$ ratio for any type of library. Some writers suggest an overall percentage based on little more than a hunch; others suggest that the percentage of serials and monographs purchased will vary depending on the discipline.

The authors believe that it is possible to determine guidelines for developing a serial/monograph ratio for research library budgeting based on objective criteria. We 
propose that, for a research library, the percentage of serials and monographs purchased should correlate with the characteristics of literature usage in each subject area. Citation studies conducted over the past 60 years covering most subject areas have been analyzed to determine the serial/monograph usage for each subject. Using the data presented in table 3 , a research library with a current book allocation formula can determine its own appro- priate serial/monograph ratio for each subject using a simple formula.

In conclusion, we find that there is no one optimum serial/monograph ratio for all research libraries. Rather, the ratio for each library will vary depending on its own priorities and emphases. For each subject, however, the serial/monograph ratio should be based on the use of the literature by researchers in that subject area as determined by citation studies.

\section{REFERENCES AND NOTES}

1. See, for example, Andrew D. Osborn, Serial Publications: Their Place and Treatment in Libraries, 3rd ed. (Chicago: American Library Assn., 1980), p.10; Marcia Tuttle, Introduction to Serials Management (Greenwich, Conn.: JAI Press, 1983), p.6.

2. Herbert S. White, "Strategies and Alternatives in Dealing With the Serials Management Budget," in Serials Collection Development: Choices and Strategies (Ann Arbor, Mich.: The Pierian Press, 1981), p.31-32.

3. Ibid., p.32.

4. David C. Taylor, Managing the Serials Explosion: The Issues for Publishers and Libraries (White Plains, N.Y.: Knowledge Industry Publications, 1982), p.19-21.

5. See, for example, William E. McGrath, "A Pragmatic Book Allocation Formula for Academic and Public Libraries with a Test for Its Effectiveness, " Library Resources and Technical Services 19:356-69 (Fall 1975); Bette Dillehay, "Book Budget Allocation: Subjective or Objective Approach," Special Libraries 62:509-14 (Dec. 1971); Joseph J. Kohut, "Allocating the Book Budget: A Model," College E Research Libraries 35:192-99 (May 1974); Steven D. Gold, "Allocating the Book Budget: An Economic Model," College E Research Libraries 36:397-410 (Sept. 1975).

6. Joseph J. Kohut and John F. Walker, "Allocating the Book Budget: Equity and Economic Efficiency," College E Research Libraries 36:403-10 (Sept. 1975).

7. See, for example, "Factors in Designing an Allocation System" [at Cornell University], in G. Edward Evans, Developing Library and Information Center Collections, 2nd ed. (Littleton, Colo.: Libraries Unlimited, 1987), p.267-69.

8. Kohut, "Allocating the Book Budget: A Model," p.192-99.

9. Robert D. Stueart and George B. Miller, eds. Collection Development in Libraries: A Treatise (Greenwich, Conn.: JAI Press, 1980), v.2, p.508; v.1, p.59.

10. Rose Mary Magrill and Doralyn J. Hickey, Acquisitions Management and Collection Development in Libraries (Chicago: American Library Assn., 1984), p.160.

11. "Standards for University Libraries," College E Research Libraries News 40:101-10 (Apr. 1979).

12. David L. Perkins, ed., Guidelines for Collection Development (Chicago: American Library Assn., 1979), p.35-36.

13. Kohut, "Allocating the Book Budget: A Model," p.192.

14. Ibid., p.193.

15. White, "Strategies and Alternatives," p.33-34.

16. Luke Swindler, "Developing the Serial Collection," in Tuttle, Introduction to Serials Management, p.20-23.

17. Ibid., p.23. 